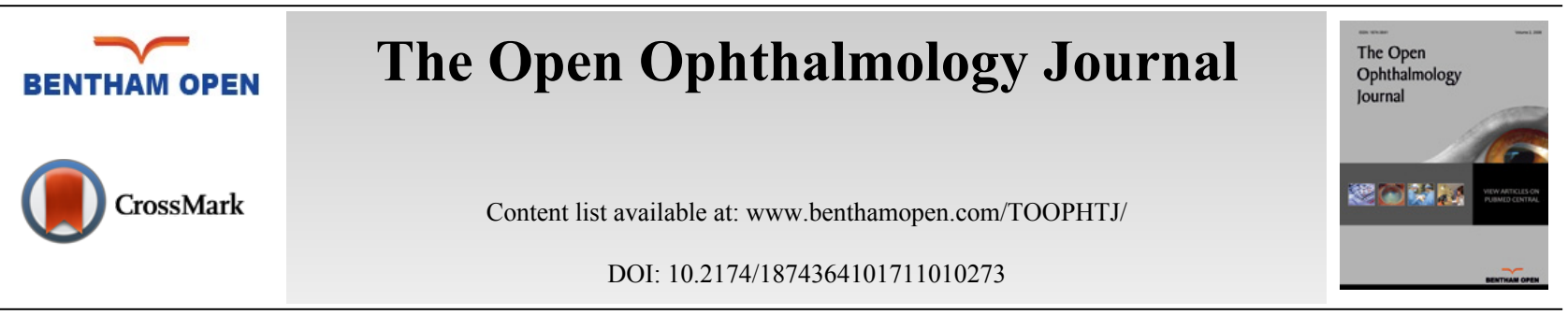

REVIEW ARTICLE

\title{
Ocular Signs Related to Overweight and Arterial Hypertension in Children: A Systematic Review
}

Daniela S. Schuh, Ângela B. Piccoli, Raquel L. Paiani, Cristiane R Maciel, Lucia C Pellanda and Manuel AP Vilela*

Instituto de Cardiologia/Fundação Universitária de Cardiologia, Porto Alegre, Brazil; Universidade Federal de Ciências da Saúde de Porto Alegre, Porto Alegre, Brazil

\section{Abstract:}

\section{Background:}

The ocular effects of obesity and hypertension need to be established and can be used as prognostic markers.

\section{Objective:}

To estimate the prevalence of ophthalmological alterations in children and adolescents who are overweight and/or have SAH.

\section{Methods:}

The database for this study included all observational studies (CS, cohort, case-control and "baseline" description of randomized clinical trials) with children and/or adolescents who were overweight, obese or had SAH and that measured ophthalmological alterations.

\section{Results:}

Comparative studies with healthy children demonstrated positive association between body adiposity with retinal venular dilation, and SAH with retinal arteriolar narrowing. Different retinal fundus cameras and computer-assisted programs to evaluate the retinal vessels, variations in the methods of analysis, adjustments, populations, were the main arguments against formal meta-analysis. The heterogeneity was too high $\left(\mathrm{I}^{2}>90 \%\right.$, in fixed or randomized effects), and the lack of linearity, normal distribution and homoscedasticity did not recommend meta-regression.

\section{Conclusion:}

Obesity and SAH show associations with ophthalmological alterations, especially with retinal vessel diameter. Lack of standardization does not allow a quantitative evaluation.

Keywords: Child obesity, Systemic arterial hypertension, Retinopathy, Retinal vessels, Eyes abnormalities.

\section{INTRODUCTION}

Child obesity has been recognized as a global public health problem which can negatively affect almost all the body's organs and cause relevant disorders such as asthma, early onset of puberty, glomerulopathy, misaligned lower limbs, hypertension, cardiovascular disease, white brain matter damage and mortality [1 - 6]. Worldwide, there are 1.1 billion obese and overweight people and $10 \%-25 \%$ of children are estimated to be affected by this situation [7 - 9]. Recent estimates calculate that there are between 42.4 and 51.8 million children and adolescents aged 0-18 in this

\footnotetext{
* Address correspondence to this author at the Instituto de Cardiologia/Fundação Universitária de Cardiologia, Porto Alegre, Brazil, Universidade
} Federal de Ciências da Saúde de Porto Alegre, Porto Alegre, Brazil, Tel: +55 51 3395360; E-mail: mapvilela@gmail.com 
context in Latin America [8].

With regard to children in particular, the mechanisms underlying the association between obesity and SAH and microvascular disease, however, have yet to be enlightened. Assessment of retinal circulation has been proposed as a way of estimating systemic microcirculation and detecting the first signs of systemic cardiovascular and cerebrovascular disease in clinical practice [10 - 12].

The morphology and flow in the retinal vessels (caliber, tortuosity, branching patterns, fractal dimensions, flow) are markers frequently analyzed. It is almost consensus that in adults the narrower the retinal arteriolar vessel, the greater the possibility of association with SAH [13], cerebrovascular accidents $[11,12,14]$ and coronary artery disease [15, 16]; whilst the wider the retinal vein diameter, the greater the associations with systemic inflammation and obesity [17, 18]. Cross-sectional(CS) population-based studies have shown that increased body mass indices (BMI) are associated with retinal arteriolar narrowing and increased retinal venular diameter among adults [19 - 21]. These findings are in agreement with data from studies with healthy child populations, indicating a possible effect of obesity and/or SAH on early alterations to microvascular structure in childhood [22 - 25].

Despite the evidence, the results regarding independent association between obesity (with or without SAH) and alterations in retinal vessels caliber (RVC) in children and adolescents are heterogeneous and the mechanisms are still unclear [26]. The only review on this topic includes perinatal risk factors (low weight, gestational age), environmental factors (physical activity, diet, family hypertension), systemic factors (hypertension, obesity) and diseases associated with future cardiovascular changes. However, it limited searches to a few databases, restricted languages, included only articles accessible to the authors' library, and did not make a qualitative risk analysis of the studies [27].

Studies involving adult populations do not have full control over confounding factors inherent to this age group relating to arterial pressure, diabetes, smoking, use of medication and it is therefore of interest to know the results of studies conducted with healthy children and youth [22]. The body mass index (BMI) in children is considered normal between percentile 3 and 85; low weight below percentile 3; overweight between percentile 85 and 97 and obesity when above percentile 97, as established by the World Health Organization in 2007 for children and adolescents (10-19 yearsold). These take into consideration adolescent growth spurt [26].

This study therefore seeks to assess, by means of a systematic review of observational studies, the presence of ophthalmological alterations in children and adolescents who are overweight or have SAH.

\section{METHODS}

\subsection{Protocol and Registration}

This systematic review was conducted in accordance with Cochrane [28], PRISMA [29] ("Preferred Reporting Items for Systematic Reviews and Meta-Analysis"), and MOOSE [30] ("Meta-analysis of Observational Studies in Epidemiology") criteria, and has been registered on the PROSPERO database [31] ("International Prospective Register of Systematic Reviews").

\subsection{Eligibility Criteria}

All articles published up until May 2017 held on the MEDLINE ("Medical Literature Analysis and Retrieval System Online") via PubMed; Embase; Scopus; Web of Science; BVS databases were considered, with no restriction as to language. Manual searches in periodicals, references used in included articles and citation analysis were also taken into consideration.

The database for this study included all observational studies (CS, cohort, case-control and "baseline" description of randomized clinical trials) with children and/or adolescents, aged 6 to 18, with cardiovascular risk factors (overweight, obesity or hypertension) which had ophthalmological abnormalities or alterations as their outcome.

The initial search used the MeSH terms "Child", "Adolescent", "Overweight", "Obesity", "Pediatric Obesity", "Hypertension", "Visual Acuity”, "Blindness", "Visual Perception", "Vision, Ocular", "Retina”, "Retinal Diseases", "Retinal Vessels", "Refractive Errors”, "Eye Injuries”, “Amblyopia”, "Vision, Binocular", "Glaucoma”, "Cataract”, "Optic Nerve Injuries", "Hypertensive Retinopathy”, “Ocular Hypertension”, "Optic Disk”, as well as related publication titles. The full search strategy used for the PubMed database is shown in Appendix 1. 


\subsection{Study Selection}

The articles selected from the databases were divided into two batches under the responsibility of two reviewers each, so that there were four different reviewers overall. Article titles and abstracts were assessed independently by each reviewer. When abstracts did not provide sufficient information as to the eligibility criteria, the entire text was assessed. The reviewers assessed the full text of the articles independently from each other and determined study eligibility. Disagreements were solved by consensus and if they persisted the opinion of a fifth reviewer specialized in the theme in question was sought (Fig. 1).
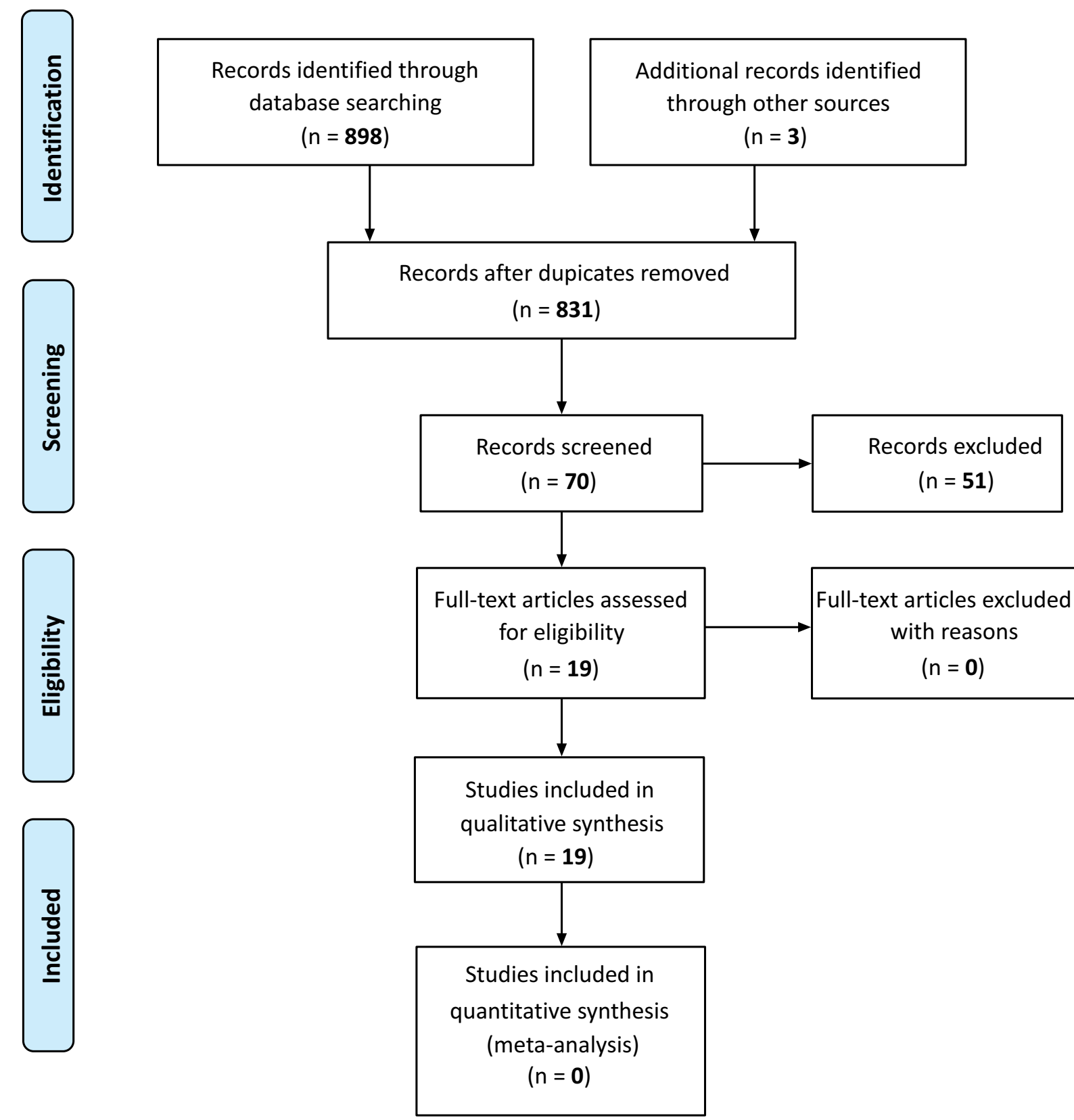

Fig. (1). Study flowchart.

\subsection{Study Quality}

Risk of bias was assessed in each study according to the Newcastle-Ottawa Scales [32] and the scales proposed by Loney et al. [33] The following parameters were considered in the case of cohort studies: sample representativeness, eligibility criteria, ascertainment of exposure, demonstration that the outcome of interest was not present at the start of the study, design or analysis comparability, results evaluation, and sufficient follow-up time for the results to occur. The 
following parameters were considered in the case of CS studies: adequacy of study design and sampling method, sample size, appropriateness of sampling frame, objective, suitable and standard criteria used for the measurement of health outcome; unbiased assessment; response rates, description of losses, appropriate expression of prevalence or incidence estimates detailed by subgroups, given with confidence intervals; study subject and results. The items considered with regard to case-control studies were case representativeness, control definition and selection, case and control comparison on the basis of design, case ascertainment, use of the same method to ascertain cases and controls, same rate for both groups, and description of losses.

\subsection{Data Extraction}

Four reviewers worked independently; two reviewers worked on the analysis of $50 \%$ of the articles and the other two reviewers worked on the other $50 \%$. Disagreements were settled by a fifth reviewer. Overall qualitative or quantitative characteristics of the studies were gathered, such as: nature of the study, population of children/youths aged 6-18, outcome relating to ophthalmological alterations based on assessment of BMI, weight and blood pressure.

\subsection{Data Analysis}

It was not possible to perform a meta-analysis owing to the discrepancy in the methods used to measure the outcomes in the studies and the discrepancies between the data reported in the articles obtained using these methods. Different retinal fundus cameras and computer-assisted programs to evaluate the retinal vessels, variations in the methods of analysis, adjustments, populations, were the main arguments against formal meta-analysis. The heterogeneity was too high ( $\mathrm{I}^{2}>90 \%$, in fixed or randomized effects), and the lack of linearity, normal distribution and homoscedasticity did not recommend meta-regression.

\section{RESULTS}

Fig. (1) shows that 901 studies were identified, 19 of which were included in this analysis. Three studies assessed both SAH and overweight [34, 36, 37]. Further five studies assessed SAH [10, 38 - 41] and the remaining eleven studies assessed the effects of overweight [6, 22, 24, 25, 35, 42 - 47], as described in Tables (1 and 2). The methodological quality of the studies is described in (Table $\mathbf{3}$ ).

Table 1. Characteristics of the Studies assessing Hypertension, or Hypertension and Obesity as a Risk Factor

\begin{tabular}{|c|c|c|c|c|c|c|c|}
\hline Author (year) & Design & $\begin{array}{c}\text { Sample } \\
\text { (n) }\end{array}$ & $\begin{array}{c}\text { Age - years } \\
(\mathbf{m} \pm \mathbf{s d})\end{array}$ & $\begin{array}{c}\text { Male Sex n } \\
\quad(\%)\end{array}$ & $\begin{array}{c}\text { Main characteristics } \\
\text { relating to hypertension }\end{array}$ & Outcome(s) & Result(s) \\
\hline $\begin{array}{l}\text { Daniels et al. } \\
\text { (1991) [38] }\end{array}$ & $\mathrm{CS}$ & 97 & $14.7 \pm 3.5$ & $73(75.2)$ & AP (last quartile) & $\begin{array}{l}\text { Qualitative analysis of vessel } \\
\text { caliber during retinography }\end{array}$ & $\begin{array}{c}41 \% \text { narrowing, } 14 \% \\
\text { tortuous, } 8 \% \\
\text { intertwined a/v } \\
\end{array}$ \\
\hline $\begin{array}{l}\text { Mitchell et al. } \\
\text { (2007) [10] }\end{array}$ & $\mathrm{CS}$ & 1952 & $\begin{array}{c}\text { Sidney } \\
6.3 \pm 0.4 \\
\text { Singapore } \\
7.6 \pm 0.6\end{array}$ & $\begin{array}{c}\text { Sidney } \\
992(50.8) \\
\text { Singapore } \\
1109(56.8)\end{array}$ & $\mathrm{AP}$ (mean and quartiles) & $\begin{array}{c}\text { Refraction }+ \\
\text { Biometry }+ \\
\text { Quantitative analysis of } \\
\text { vessel caliber during } \\
\text { retinography }\end{array}$ & $\begin{array}{l}\text { Spherical Equivalent } \\
\text { (D): } \\
+0.4 \text { to }-4.25 \\
\text { Axial Length }(\mathrm{mm}) \text { : } \\
21.9 \text { to } 25.2 \\
\text { RAC reduced in the } \\
\text { highest quartile } \\
\text { RVC not associated }\end{array}$ \\
\hline $\begin{array}{l}\text { Gopinath et al. } \\
\text { (2010) [39] }\end{array}$ & $\mathrm{CS}$ & 2272 & $12.7 \pm 0.4$ & $1154(50.8)$ & AP (mean and quartiles) & $\begin{array}{l}\text { Quantitative analysis of } \\
\text { vessel caliber during } \\
\text { retinography }\end{array}$ & $\begin{array}{c}\text { CAV reduced } \\
\text { RVC not associated }\end{array}$ \\
\hline $\begin{array}{l}\text { Hanssen et al. } \\
\text { (2012) [36] }\end{array}$ & $\mathrm{CS}$ & 578 & $11.1 \pm 0.6$ & $329(56.9)$ & $\begin{array}{c}\text { AP } \\
\text { BMI }>90 \text { th percentile }\end{array}$ & $\begin{array}{l}\text { Quantitative analysis of } \\
\text { vessel caliber during } \\
\text { retinography }\end{array}$ & $\begin{array}{c}\text { RAC reduced } \\
\text { RVC not associated }\end{array}$ \\
\hline $\begin{array}{l}\text { Kurniawan, E.D. } \\
\text { et al. (2012) [40] }\end{array}$ & $\mathrm{CS}$ & 1174 & $11.9 \pm 1.0$ & $576(49.1)$ & $\mathrm{AP}, \mathrm{SP}, \mathrm{DP}$ & \begin{tabular}{|c|} 
Refraction + \\
Biometry + \\
Quantitative analysis of \\
caliber and circulation pattern \\
in vessels during \\
retinography
\end{tabular} & \begin{tabular}{|} 
Spherical Equivalent \\
(dioptres): \\
$-0.33( \pm 1.67)$ not \\
related \\
Axial Length $(\mathrm{mm}):$ \\
$23.27( \pm 0.9)$ not related \\
Retinal Fractal \\
Dimension reduced \\
RAC reduced \\
RVC not related
\end{tabular} \\
\hline
\end{tabular}


(Table 1) contd.....

\begin{tabular}{|c|c|c|c|c|c|c|c|}
\hline Author (year) & Design & $\begin{array}{l}\text { Sample } \\
\text { (n) }\end{array}$ & $\begin{array}{c}\text { Age - years } \\
(\mathbf{m} \pm \mathbf{s d})\end{array}$ & $\begin{array}{c}\text { Male Sex n } \\
(\%)\end{array}$ & \begin{tabular}{|c|} 
Main characteristics \\
relating to hypertension
\end{tabular} & Outcome(s) & Result(s) \\
\hline $\begin{array}{l}\text { Murgan et al. } \\
(2013)[41]\end{array}$ & $\mathrm{CS}$ & 121 & $16.2 \pm 1.5$ & $68(56.2)$ & $\begin{array}{c}\text { AP }>90 \text { th percentile } 90 \text { th } \\
\text { percentile, but below } \\
\text { 95th percentile, or if } \\
\text { arterial pressure exceeded } \\
120 / 80 \mathrm{mmHg}\end{array}$ & $\begin{array}{l}\text { Quantitative analysis of } \\
\text { vessel caliber during } \\
\text { retinography }\end{array}$ & $\begin{array}{l}\text { RAC reduced in SAH } \\
\text { RVC not related } \\
\text { Relação caliber a/v: not } \\
\text { related }\end{array}$ \\
\hline $\begin{array}{l}\text { Yang et al. } \\
(2014)[34]\end{array}$ & CS & 1565 & $11.9 \pm 3.5$ & $801(51.2)$ & AP last quartile and BMI & $\begin{array}{c}\text { Refraction }+ \\
\text { Biometry }+ \\
\text { Intraocular Pressure (IOP): } \\
\text { (non-contact) }\end{array}$ & $\begin{array}{c}\text { SE (D): } \\
-1.58 \pm 2.0 \text { (no } \\
\text { relationship) } \\
\text { AL(mm): } \\
17.1 \pm 3.6 \text { (no } \\
\text { relationship) } \\
\text { IOP associated with } \\
\text { diastolic pressure; not } \\
\text { related to BMI }\end{array}$ \\
\hline $\begin{array}{l}\text { Imhof et al. } \\
(2016) \text { [37] }\end{array}$ & $\mathrm{CS}$ & 391 & $7.3+-0.4$ & $191(48.8)$ & $\begin{array}{l}\text { AP }>95 \text { th percentile } \\
\text { BMI }(\mathrm{WHO})\end{array}$ & $\begin{array}{l}\text { Quantitative analysis of } \\
\text { vessel caliber during } \\
\text { retinography }\end{array}$ & $\begin{array}{l}\text { SAH:RAC reduced } \\
\text { RVC not related; } \\
\text { Obesity: RAC/RVC not } \\
\text { related after adjustment } \\
\text { for blood pressure }\end{array}$ \\
\hline
\end{tabular}

$\mathrm{AL}=$ axial length of the globe of the eye, $\mathrm{AP}=$ arterial pressure, $\mathrm{BMI}=$ body mass index, $\mathrm{D}=$ dioptre, $\mathrm{DP}=$ diastolic pressure, Intertwined $\mathrm{a} / \mathrm{v}=$ artery/vein intertwined, $\mathrm{IOP}=$ intraocular pressure, Narrowing = retinal arteriolar narrowing, $\mathrm{RAC}=$ retinal arteriolar caliber, $\mathrm{RVC}=$ retinal venular caliber, $\mathrm{SE}=$ spherical equivalent, $\mathrm{SP}=$ systolic pressure, $\mathrm{sd}=$ standard deviation, $\mathrm{CS}=$ cross-sectional.

Table 2. Characteristics of the Studies assessing Obesity as a Risk Factor

\begin{tabular}{|c|c|c|c|c|c|c|c|}
\hline Author (year) & Design & $\begin{array}{l}\text { Sample } \\
\text { (n) }\end{array}$ & Age $(\mathrm{m} \pm$ sd) & $\begin{array}{c}\text { Male Sex } \\
\text { n (\%) }\end{array}$ & $\begin{array}{c}\text { Main characteristics } \\
\text { relating to obesity }\end{array}$ & Outcome(s) & Result(s) \\
\hline $\begin{array}{l}\text { Saw et al. } \\
(2002)[42]\end{array}$ & $\mathrm{CS}$ & 1449 & $8( \pm 1)$ & $\begin{array}{c}746 \\
(51.5)\end{array}$ & BMI (quartiles) & Refraction & $\begin{array}{c}\text { Weight related to } \\
\text { hypermetropy boys } \\
\text { Height related to myopia }\end{array}$ \\
\hline $\begin{array}{c}\text { Akinci et al. (2007) } \\
\text { [35] }\end{array}$ & Case-control & $\begin{array}{c}72(\mathrm{BMI} \\
>95) \\
72(\mathrm{BMI} \\
<95)\end{array}$ & \begin{tabular}{|c|} 
Group I Boys \\
$13.7(2.6)$ \\
Girls \\
$14.6(1.8)$ \\
Group C \\
Boys \\
$13.6(2.7)$ \\
Girls \\
$14.5(1.9)$ \\
$>0.05$ \\
\end{tabular} & $49(68)$ & BMI $>95^{\text {th }}$ percentile & $\begin{array}{l}\text { Exophtham (Hertel) } \\
\text { IOP (applanation) }\end{array}$ & \begin{tabular}{|c}
$18 \%$ obese with \\
exophthalmia \\
IOP not associated with \\
blood pressure levels \\
$10 \%$ obese with \\
increased IOP
\end{tabular} \\
\hline $\begin{array}{l}\text { Cheung et al. } \\
(2007)[22]\end{array}$ & $\mathrm{CS}$ & 768 & $7.9 \pm 0.8$ & $\begin{array}{c}403 \\
(52.5)\end{array}$ & BMI (quartiles) & $\begin{array}{l}\text { Quantitative analysis of } \\
\text { vessel caliber during } \\
\text { retinography }\end{array}$ & $\begin{array}{c}\text { RAC: not associated } \\
\text { RVC: increased (every } \\
3.1 \mathrm{~kg} / \mathrm{m}^{2} \text { BMI increases } \\
\text { vein } 2.55 \mu)\end{array}$ \\
\hline $\begin{array}{l}\text { Gopinath et al. } \\
\text { (2011) [24] }\end{array}$ & $\mathrm{CS}$ & 2353 & $12.7 \pm 0.4$ & $\begin{array}{l}1188 \\
(50.5)\end{array}$ & BMI (IOTF) & $\begin{array}{l}\text { Quantitative analysis of } \\
\text { vessel caliber during } \\
\text { retinography }\end{array}$ & $\begin{array}{l}\text { RAC: decreased } \\
\text { RVC: increased }\end{array}$ \\
\hline Li et al. (2011) [43] & $\mathrm{CS}$ & 136 & $11.19 \pm 2.5$ & $69(50.1)$ & $\begin{array}{c}\text { BMI }>85 \% \\
\text { percentile } \\
\text { Triceps skin fold }\end{array}$ & $\begin{array}{l}\text { Quantitative analysis of } \\
\text { vessel caliber during } \\
\text { retinography }\end{array}$ & $\begin{array}{l}\text { RAC: not associated } \\
\text { RVC: increased }\end{array}$ \\
\hline $\begin{array}{l}\text { Albuquerque et al } \\
\text { (2013) [44] }\end{array}$ & $\mathrm{CS}$ & 96 & $11 \pm 2.8$ & $46(48)$ & $\begin{array}{l}\mathrm{BMI} \geq 95 \% \\
\text { percentile }\end{array}$ & IOP (applanation) & IOP not associated \\
\hline $\begin{array}{l}\text { Jiang et al. } \\
(2014)[46]\end{array}$ & $\mathrm{CS}$ & 5919 & $10.0 \pm 3.3$ & $\begin{array}{l}3118 \\
(52.7)\end{array}$ & BMI & IOP (non-contact) & $\begin{array}{c}\text { IOP associate with BMI } \\
\text { in boys }\end{array}$ \\
\hline $\begin{array}{l}\text { Kurniawan et al. } \\
\text { (2014) [47] }\end{array}$ & Cohort & 421 & $11.9 \pm 0.8$ & $\begin{array}{c}207 \\
(49.2)\end{array}$ & BMI (WHO) & $\begin{array}{c}\text { Refraction }+ \\
\text { Quantitative analysis of } \\
\text { vessel caliber during } \\
\text { retinography }\end{array}$ & $\begin{array}{l}\text { SE (D): }-2.23 \pm 1.4 \\
\text { RAC: no relationship } \\
\text { RVC: increased }\end{array}$ \\
\hline $\begin{array}{l}\text { Yau et al. } \\
(2014)[6]\end{array}$ & $\mathrm{CS}$ & $\begin{array}{l}39 \text { cases } \\
51 \\
\text { controls }\end{array}$ & $17.8 \pm 1.6$ & $15(38.4)$ & IR (QUICKI) & $\begin{array}{l}\text { Quantitative analysis of } \\
\text { vessel caliber during } \\
\text { retinography }\end{array}$ & $\begin{array}{l}\text { RAC: decreased } \\
\text { RVC: increased }\end{array}$ \\
\hline
\end{tabular}


(Table 2) contd.....

\begin{tabular}{|c|c|c|c|c|c|c|c|}
\hline Author (year) & Design & $\begin{array}{c}\text { Sample } \\
\text { (n) }\end{array}$ & Age $(\mathbf{m} \pm$ sd) & \begin{tabular}{|c|} 
Male Sex \\
n (\%)
\end{tabular} & $\begin{array}{l}\text { Main characteristics } \\
\text { relating to obesity }\end{array}$ & Outcome(s) & Result(s) \\
\hline $\begin{array}{c}\text { Gishti et al. (2015) } \\
\text { [45] }\end{array}$ & $\mathrm{CS}$ & 4145 & $6.0+-0.3$ & $2072(50)$ & $\begin{array}{c}\mathrm{BMI} \geq 95 \% \\
\text { percentile }\end{array}$ & $\begin{array}{l}\text { Quantitative analysis of } \\
\text { vessel caliber during } \\
\text { retinography }\end{array}$ & $\begin{array}{l}\text { RAC decreased } \\
\text { RVC not related }\end{array}$ \\
\hline $\begin{array}{l}\text { Xiao et al. } \\
(2015)[25]\end{array}$ & $\mathrm{CS}$ & 731 & $\begin{array}{c}\text { Subgroup 1: } \\
7-11 \mathrm{y} \\
\text { Girls } 9.4 \pm 1.2 \\
\text { Boys } \\
9.62 \pm 1.36 \\
\text { Subgroup 2: } \\
12-19 \text { a } \\
\text { Girls } 14.5 \pm 2 \\
\text { Boys } \\
14.3 \pm 2.4\end{array}$ & $\begin{array}{c}339 \\
(46.3)\end{array}$ & BMI & $\begin{array}{l}\text { Quantitative analysis of } \\
\text { vessel caliber during } \\
\text { retinography }\end{array}$ & $\begin{array}{c}\text { RAC and RVC: between } \\
12-19 \text { years narrowing } \\
\text { related to adiposity }\end{array}$ \\
\hline
\end{tabular}

$\mathrm{AP}=$ arterial pressure, $\mathrm{BMI}=$ body mass index, $\mathrm{IOP}=$ intraocular pressure, $\mathrm{IOTF}=$ International Obesity Task Force, $\mathrm{IR}$ $(\mathrm{QUICKI})=$ index of resistance to insulin and method, $\mathrm{RAC}=$ retinal arteriolar caliber, $\mathrm{RVC}=$ retinal venular caliber, $\mathrm{WHO}=$ World Health Organization, $\mathrm{sd}=$ standard deviation, $\mathrm{CS}=$ cross-sectional, Exophtham $=$ exophthalmometry

Table 3. Summary of Study Quality (with all scales used)

\begin{tabular}{|c|c|c|c|c|c|c|c|c|c|c|c|c|c|c|c|}
\hline Reference & \multicolumn{2}{|c|}{$\begin{array}{l}\text { Are the study design and } \\
\text { sampling method } \\
\text { appropria-te for the } \\
\text { research question? }\end{array}$} & $\begin{array}{c}\text { Is the sampling } \\
\text { frame appropri- } \\
\text { ate? }\end{array}$ & $\begin{array}{c}\text { Is the sample size } \\
\text { adequate? }\end{array}$ & \multicolumn{2}{|c|}{$\begin{array}{c}\text { Are objective, } \\
\text { suitable and } \\
\text { standard criteria } \\
\text { used for measure- } \\
\text { ment of the health } \\
\text { outcome? }\end{array}$} & \multicolumn{2}{|c|}{\begin{tabular}{|c|} 
Is the health \\
outcome measured \\
in an unbiased \\
fashion?
\end{tabular}} & \multicolumn{2}{|c|}{$\begin{array}{l}\text { Is the response rate } \\
\text { adequate? Are the } \\
\text { refusers described? }\end{array}$} & \multicolumn{2}{|c|}{$\begin{array}{c}\text { Are the estimates } \\
\text { of prevalence or } \\
\text { incidence given } \\
\text { with confidence } \\
\text { intervals and in } \\
\text { detail by } \\
\text { subgroup, if } \\
\text { appropriate? }\end{array}$} & \multicolumn{2}{|c|}{\begin{tabular}{|c|} 
Are the study \\
subjects and the \\
setting \\
described in \\
detail and \\
similar to those \\
of interest to \\
you?
\end{tabular}} & Score \\
\hline (6) & 1 & & 1 & ND & 1 & & 1 & & & 1 & 1 & & & 1 & 7 \\
\hline (10) & 1 & & 1 & ND & 1 & & 1 & & & 1 & 1 & & & 1 & 7 \\
\hline (22) & 1 & & 1 & ND & 1 & & 1 & & & 1 & 1 & & & 1 & 7 \\
\hline (24) & 1 & & 1 & ND & 1 & & 1 & & & 1 & 1 & & & 1 & 7 \\
\hline (25) & 1 & & 1 & $\mathrm{ND}$ & 1 & & 1 & & & 1 & 1 & & & 1 & 7 \\
\hline (34) & 1 & & 1 & ND & 1 & & 1 & & & 1 & 1 & & & 1 & 7 \\
\hline (36) & 1 & & 1 & $\mathrm{ND}$ & 1 & & 1 & & & 1 & 1 & & & 1 & 7 \\
\hline (37) & 1 & & 1 & ND & 1 & & 1 & & & 1 & 1 & & & 1 & 7 \\
\hline (38) & - & & - & $\mathrm{ND}$ & 1 & & 1 & & & 1 & - & & & 1 & 5 \\
\hline (39) & 1 & & 1 & ND & 1 & & 1 & & & 1 & 1 & & & 1 & 7 \\
\hline (40) & 1 & & 1 & ND & 1 & & 1 & & & 1 & 1 & & & 1 & 7 \\
\hline$(41)$ & 1 & & 1 & $\mathrm{ND}$ & 1 & & 1 & & & 1 & 1 & & & 1 & 7 \\
\hline (42) & 1 & & 1 & ND & 1 & & 1 & & & 1 & 1 & & & 1 & 7 \\
\hline (43) & 1 & & 1 & $\mathrm{ND}$ & 1 & & 1 & & & 1 & 1 & & & 1 & 7 \\
\hline (44) & 1 & & 1 & ND & 1 & & 1 & & & 1 & 1 & & & 1 & 7 \\
\hline (45) & 1 & & 1 & $\mathrm{ND}$ & 1 & & 1 & & & 1 & 1 & & & 1 & 7 \\
\hline (46) & 1 & & 1 & $\mathrm{ND}$ & 1 & & 1 & & & 1 & 1 & & & 1 & 7 \\
\hline Reference & $\begin{array}{r}\text { Representativenes } \\
\text { exposed coho }\end{array}$ & of the & $\begin{array}{c}\text { Selection of the } \\
\text { non exposed cohort }\end{array}$ & $\begin{array}{l}\text { Ascertainment of } \\
\text { exposure }\end{array}$ & $\begin{array}{r}\text { Demonstratio } \\
\text { outcome of in } \\
\text { was not present } \\
\text { of study }\end{array}$ & $\begin{array}{l}\text { n that } \\
\text { terest } \\
\text { at start }\end{array}$ & $\begin{array}{r}\text { Comparabilit } \\
\text { cohorts on the } \\
\text { of the desig } \\
\text { analysis }\end{array}$ & \begin{tabular}{l|} 
ity of \\
e basis \\
gn or \\
s
\end{tabular} & Assess & sment of outcome & \begin{tabular}{|c|}
$\begin{array}{r}\text { Was follow-u } \\
\text { enough f } \\
\text { outcomes to }\end{array}$
\end{tabular} & $\begin{array}{l}\text { p long } \\
\text { or } \\
\text { occur }\end{array}$ & & $\begin{array}{l}\text { dequacy of } \\
\text { dlow-up of } \\
\text { cohorts }\end{array}$ & \begin{tabular}{|c|} 
Newcastle \\
- Ottawa \\
Quality \\
Assessment \\
Scale \\
Cohort \\
Studies \\
\end{tabular} \\
\hline (47) & * & & $*$ & $*$ & $*$ & & $* *$ & & & * & & & & * & 8 \\
\hline Reference & $\begin{array}{c}\text { Is the case definition } \\
\text { adequate? }\end{array}$ & $\begin{array}{r}\text { Represe } \\
\text { th }\end{array}$ & $\begin{array}{l}\text { entativeness of } \\
\text { he cases }\end{array}$ & $\begin{array}{l}\text { lection of the } \\
\text { controls }\end{array}$ & $\begin{array}{l}\text { Definition of } \\
\text { controls }\end{array}$ & $\begin{array}{r}\text { Com! } \\
\text { cases at } \\
\text { the b } \\
\text { desigr }\end{array}$ & $\begin{array}{l}\text { parability of } \\
\text { and controls on } \\
\text { basis of the } \\
\text { nn or analysis } \\
\end{array}$ & $\begin{array}{r}\text { Ascerta } \\
\text { of exp }\end{array}$ & ainment & $\left|\begin{array}{c}\text { Same method } \\
\text { of } \\
\text { ascertainment } \\
\text { for cases and } \\
\text { controls }\end{array}\right|$ & $\begin{array}{l}\text { Same rate for } \\
\text { both groups }\end{array}$ & $\begin{array}{r}\mathrm{No} \\
\text { respon } \\
\text { descr }\end{array}$ & \begin{tabular}{l|} 
on \\
ndents \\
ribed
\end{tabular} & \begin{tabular}{|c|} 
sate \\
different \\
and no \\
designation
\end{tabular} & Total \\
\hline (35) & * & & & $*$ & * & & * & * & & $*$ & * & & & & $7 *$ \\
\hline
\end{tabular}

$\mathrm{ND}=$ not determined

\subsection{SAH and Ocular Manifestations}

With regard to intraocular pressure (IOP), two series had contrary results. Yang et al. [34] assessed 1565 children aged 11.9 years on average and found association between the highest quartiles of diastolic pressure and IOP, whereby IOP increased $0.5 \mathrm{mmHg}$ for every $10 \mathrm{mmHg}$ increase in arterial pressure. Akinci et al. [35] did not find association between IOP and SAH. The differences between these findings lie in their different methods and samples: the tonometry methods were not similar and the populations came from diverse ethnic groups.

Axial length (AL) and spherical equivalent (SE) did not show association with SAH and variations were attributed to the ethnic characteristics of the samples. Mitchell et al. [10] studied a cohort of two populations (1952 individuals) and in the Sydney sample AL was $22.6 \pm 0.7 \mathrm{~mm}$ and SE was $+1.3 \pm 0.9$ dioptres (D), whereas in the Singapore sample 
AL was $24.2 \pm 1.0 \mathrm{~mm}$ and SE was $-2.25 \pm 2.01 \mathrm{D}$. Kurniawan et al. [40] studied a sample of 1174 children in Singapore and found $23.27 \pm 0.93 \mathrm{~mm}$ AL and $-0.33 \pm 1.67 \mathrm{D} \mathrm{SE}$.

Reduction in retinal artery caliber was the finding most expressively associated with SAH. This was demonstrated in all the studies. In the six quantitative studies, it appeared as a significant fundoscopic marker [40 - 42]. In the qualitative study conducted by Daniels et al. [38], it was described in $41 \%$ of the children in the last quartile of SAH. For every $10 \mathrm{mmHg}$ increase in arterial pressure, Gopinath et al. [39] found a reduction of $2.08 \mu$ in Sydney children and $1.43 \mu$ in Singapore children, whilst Mitchell et al. [10] found a reduction of 1.64-2.11 $\mu$. Retinal venous caliber showed no relationship with SAH.

\subsection{Obesity and Ocular Manifestations}

Four series assessed IOP in obese children [34, 35, 44, 46]. Yang et al. [34] (1565 children, non-contact tonometry) and Albuquerque et al. [44] (96 individuals; applanation tonometry) did not find association. Akinci et al. [35] detected a $10 \%$ increase in IOP among obese children (applanation tonometry); when analyzing 5919 individuals with an average age of 10.0 \pm 3.3 years (non-contact tonometry), Jiang et al. [46] found association with IOP in obese females $(\mathrm{p}<0.001)$.

Saw et al. [42] found association between obesity and hypermetropia in boys; Kurniawan et al. [47] detected in the entire cohort $-2.23 \pm 1.45 \mathrm{D} \mathrm{SE}$, although unrelated to obesity. An isolated finding in the series studied by Akinci et al. [35] was the detection of exophthalmia in $18 \%$ of the children using the Hertel instrument. The majority of the studies found significant association between obesity and dilated retinal veins. Kurniawan et al. [47] found that for every 1 $\mathrm{kg} / \mathrm{m}^{2}$ increase in BMI, retinal venular caliber increased by $0.59 \mu$. Cheung et al. [22] found a relationship between 3.1 $\mathrm{kg} / \mathrm{m}^{2} \mathrm{BMI}$ and $2.55 \mu$ dilation in the same caliber. Diverging results were found with regard to retinal arteriolar caliber. Gopinath et al. [25], Yau et al. [6], Xiao et al. [26] and Gishti et al. [45] described retinal arteriolar narrowing in these cases; Cheung et al. [22], Kurniawan et al. [47] and Li et al. [43] did not find association between retinal artery diameter and obesity.

\section{DISCUSSION}

According to the findings of our systematic review, children with SAH and/or obesity may have retinal repercussions similar but not identical to those observed in adults, in particular arteriolar narrowing in hypertensive children and venular dilation in children with high BMI. This is due to several factors, including the status of the retinal vessels at the time of the onset of $\mathrm{SAH}$, the duration, severity and response to its management as well as prevalent comorbidities (diabetes, hypercholesterolaemia) [10, 13, 18, 19].

This evidence comes from both direct measurement and also from analyses based on the principle of the fractal dimension, whereby rarefaction of the retinal vessels can be seen [38 - 42]. The following mechanisms have been proposed regarding venous dilation among the obese: increased blood volume and increased leptin levels (the latter stimulating nitric acid synthesis), and increased pre-inflammatory factors (TNF $\alpha$ ) or inflammatory factors [38].

As such, these potential markers can be a basis for supporting diagnosis and control of these situations in childhood. Control of these factors could reduce the consequences for the target organs [48]. These vascular conditions leave traces of their presence from the onset and the marker can be used for following up on suspected cases. The difficulty lies in the routine inclusion of expensive retinal images and digital measuring systems for these vessels, considering that qualitative analysis restricts long-term follow-up of these findings to subjectivity. Moreover, as yet there is no standardized and universal acceptance or use of these quantitative estimation devices.

It must be taken into consideration that measurements made by computerized equipment are automatic estimates derived from non-uniform criteria or based on images subject to discrepancies. Moreover, the vascular zones analyzed are not always equivalent. In cases of axial myopia, or perinatal morbidities the retinal vessels tend to be narrower and these aspects may confound the results.

Based on the studies selected here, unanimity is lacking with regard to association between IOP and SAH and/or obesity [34, 35, 42, 44, 46]. Differing populations, different measurement methods (including body position), as well as the lack of more relevant data, such as corneal thickness, analysis of the optic disc and visual fields, prevent undeniable association from being established. The mechanisms suggested include (1) excessive intraorbital fat and blood hyperviscosity compromising venous drainage, (2) increased aqueous humour filtration owing to greater circulatory flow in the ciliary arteries, and (3) body position during tonometry, assuming that obese patients binding forward and 
often straining may cause alterations in measurements. It is appropriate to highlight that small differences in eye pressure measurements are not always clinically relevant [35].

The findings regarding refractive status and axial length were not different to those found in normal weight children $[10,34,40,42,46]$. Xiao and colleagues [26] found that microvascular alterations are only present in children over 12 years old, implying that obesity may be associated with microvasculature only in children near to puberty.

In adults and also similarly in children above 6 years old, the relationship between SAH and obesity, especially with regard to retinal vessels, has been demonstrated in a large number of publications. Arteriolar narrowing associated with SAH and venular dilation associated with obesity are markers of these situations. A recent systematic review and metaanalysis of 10229 adult cases concluded that in adults retinal arteriolar narrowing and retinal venular dilation are associated independently and significantly with higher risk of SAH, especially in people aged over 60. The study estimated that for every $1.12 \mathrm{mmHg}$ increase in arterial pressure there was arteriolar reduction of $20 \mu$. This data is relevant both for case prognosis and control [49].

According to the META-EYE Study Group [7] regarding a meta-analysis involving 44000 individuals, retinal arteriolar caliber reduces and venular caliber increases in obese adults when compared to those with normal weight, regardless of cardiovascular risk factors. In this case, an increase of $1 \mathrm{~kg} / \mathrm{m}^{2}$ is associated with a difference of $0.07 \mu$ [95\% CI:-0.08-0.06] in arteriolar caliber and 0.22 4 (95\% CI:021-0.23] in venous caliber. Given that these amounts correspond to a less than $1 \%$ in relation to normal calibers, their clinical significance is not clear [7]. In children these proportions regarding artery calibers in SAH and vein calibers in cases with high BMI appear to be considerably similar [22]. Even in those aged under six years old it was demonstrated that BMI and systolic arterial pressure have inverse linear associations with retinal artery caliber, and BMI has a positive linear association with vein caliber. For every kg $/ \mathrm{m}^{2}$ increase in BMI, there was a $1.06 \mu \mathrm{m}$ reduction in retinal artery caliber $(p=0.01)$ and $1.12 \mu \mathrm{m}$ widening of vein caliber $(p=0.02)$. The findings were also similar in those whose BMI was $\geq 95 \%$. And for every $10 \mathrm{~mm} \mathrm{Hg}$ increase in systolic pressure a $1.70 \mu \mathrm{m}$ reduction was found in retinal artery caliber $(p=0.02)$ [50]. So subtle differences are difficult to perceive in ophthalmoscopy, and depends on specific equipment.

The strength of this systematic review lies in the bringing together of specific studies with children, with no restriction as to language, to form a significant sample pool. There are many limitations: (1) different populations, nonstandardized and diverse methods used to assess variables, resulting in possible overestimation or underestimation, (2) the absence of prospective studies, preventing an appreciation of the causal link and the evolution of the findings over time, (3) different or imprecise criteria principally in relation to defining obesity. It was also found that the use of BMI does not accurately reflect the form of adipose tissue distribution, nor does it distinguish fat deposition from muscle hypertrophy [38].

\section{CONCLUSION}

In conclusion, children with SAH and/or obesity suffer alterations in the dimensions of their retinal blood vessels. With the aid of digital photography and special computerized equipment, it is possible to measure these alterations, but these resources have yet to be standardized. Evolving studies will be essential to determine whether the findings described can or cannot be transformed into markers.

\section{APPENDIX 1}

\begin{tabular}{|c|c|c|c|c|}
\hline Search & \begin{tabular}{|l|} 
Add to \\
Builder
\end{tabular} & Query & \begin{tabular}{|l|} 
Items \\
Found \\
\end{tabular} & Time \\
\hline \#4 & Add & Search (\#1 AND \#2 AND \#3) & 901 & $13: 40: 17$ \\
\hline \#3 & Add & 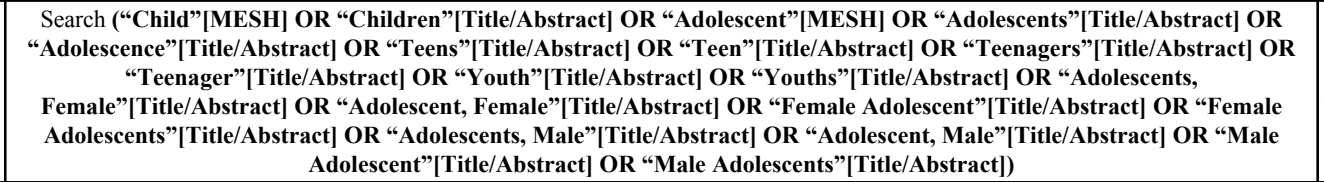 & 2671967 & $13: 39: 16$ \\
\hline$\# 2$ & Add & 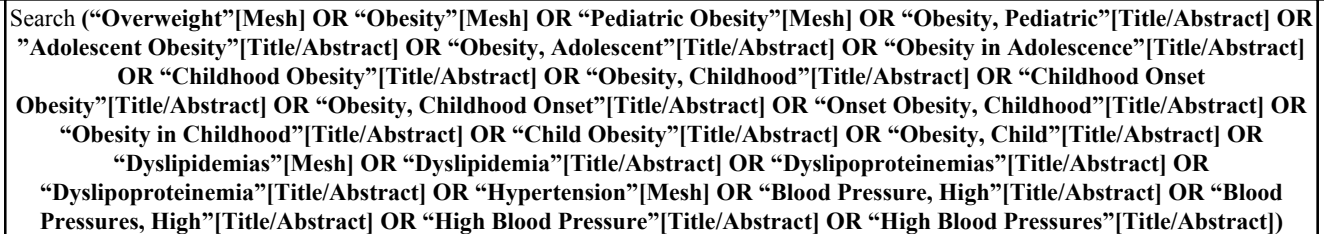 & 419714 & $13: 38: 31$ \\
\hline
\end{tabular}




\begin{tabular}{|c|c|c|c|c|}
\hline Search & $\begin{array}{l}\text { Add to } \\
\text { Builder }\end{array}$ & Query & $\begin{array}{l}\text { Items } \\
\text { Found }\end{array}$ & Time \\
\hline$\# 1$ & Add & 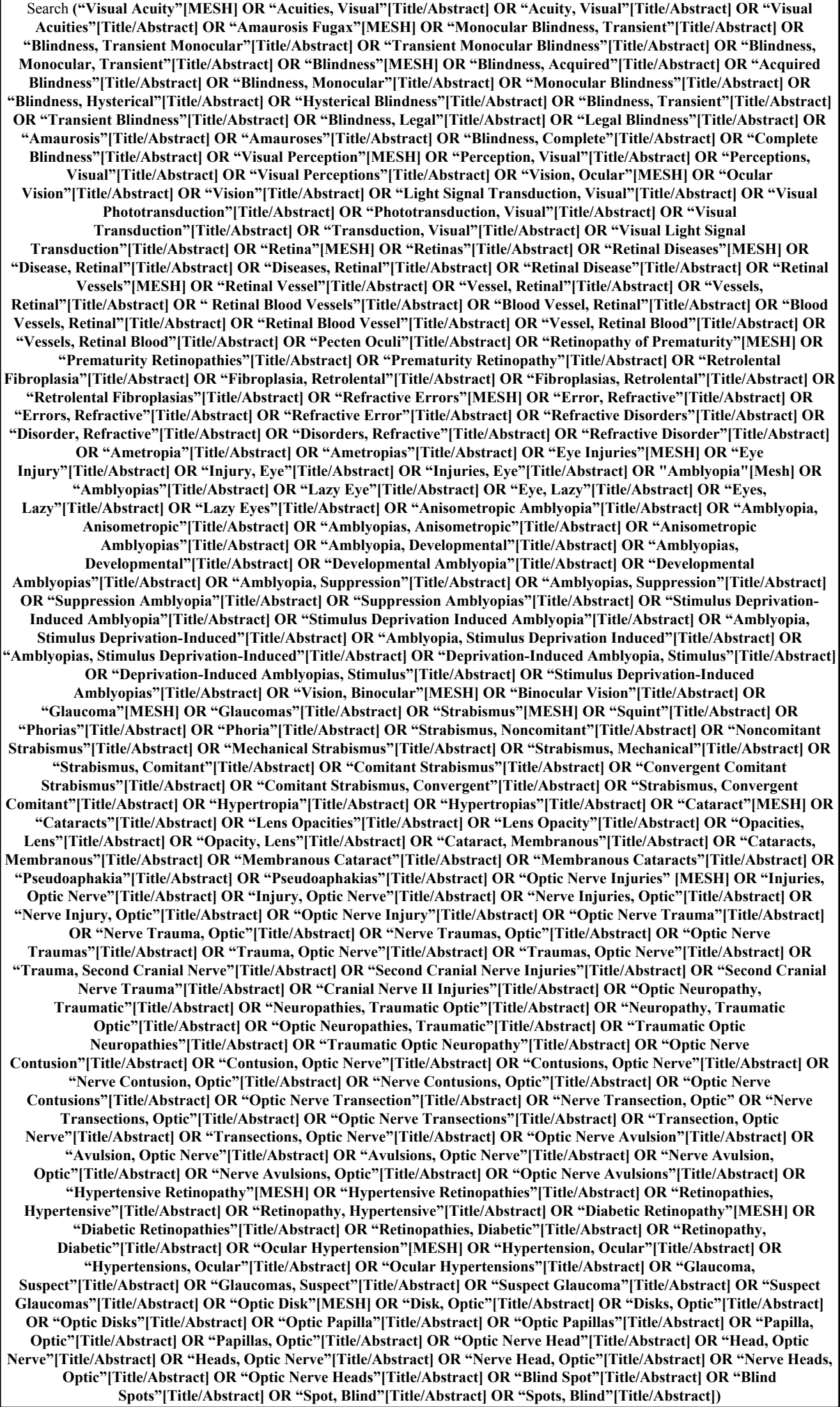 & 507949 & $13: 36: 45$ \\
\hline
\end{tabular}




\section{CONSENT FOR PUBLICATION}

Not applicable.

\section{CONFLICT OF INTEREST}

The authors declare no conflict of interest, financial or otherwise.

\section{ACKNOWLEDGEMENTS}

Declared none.

\section{REFERENCES}

[1] Thomsen SF, Ulrik CS, Kyvik KO. Association between obesity and asthma in a twin cohort. Allergy 2007; 62: 1199-204.

[2] Mamun AA, Hayatbakhsh MR, O’Callaghan M, Williams G, Najman J. Early overweight and pubertal maturation--pathways of association with young adults' overweight: A longitudinal study. Int J Obes 2009; 33(1): 14-20. [http://dx.doi.org/10.1038/ijo.2008.220] [PMID: 18982007]

[3] Savino A, Pelliccia P, Chiarelli F, Mohn A. Obesity-related renal injury in childhood. Horm Res Paediatr 2010; 73(5): 303-11. [http://dx.doi.org/10.1159/000308161] [PMID: 20389099]

[4] Taylor ED, Theim KR, Mirch MC, et al. Orthopedic complications of overweight in children and adolescents. Pediatrics 2006; 117(6): 2167-74.

[http://dx.doi.org/10.1542/peds.2005-1832] [PMID: 16740861]

[5] Baker JL, Olsen LW, Sørensen TI. Childhood body-mass index and the risk of coronary heart disease in adulthood. N Engl J Med 2007; 357(23): 2329-37. [http://dx.doi.org/10.1056/NEJMoa072515] [PMID: 18057335]

[6] Yau PL, Kim M, Tirsi A, Convit A. Retinal vessel alterations and cerebral white matter microstructural damage in obese adolescents with metabolic syndrome. JAMA Pediatr 2014; 168(12): e142815. [http://dx.doi.org/10.1001/jamapediatrics.2014.2815] [PMID: 25436854]

[7] Boillot A, Zoungas S, Mitchell P, et al. Obesity and the microvasculature: A systematic review and meta-analysis. PLoS One 2013; 8(2): e52708.

[http://dx.doi.org/10.1371/journal.pone.0052708] [PMID: 23405065]

[8] de Onis M. Preventing childhood overweight and obesity. J Pediatr (Rio J) 2015; 91(2): 105-7. [http://dx.doi.org/10.1016/j.jped.2014.10.002] [PMID: 25458878]

[9] Cheung N, Wong TY. Obesity and eye diseases. Surv Ophthalmol 2007; 52(2): 180-95. [http://dx.doi.org/10.1016/j.survophthal.2006.12.003] [PMID: 17355856]

[10] Mitchell P, Cheung N, de Haseth K, et al. Blood pressure and retinal arteriolar narrowing in children. Hypertension 2007; 49(5): 1156-62. [http://dx.doi.org/10.1161/HYPERTENSIONAHA.106.085910] [PMID: 17372033]

[11] Wong TY, Klein R, Couper DJ, et al. Retinal microvascular abnormalities and incident stroke: The atherosclerosis risk in communities study. Lancet 2001; 358(9288): 1134-40.

[http://dx.doi.org/10.1016/S0140-6736(01)06253-5] [PMID: 11597667]

[12] Liew G, Wong TY, Mitchell P, Wang JJ. Are narrower or wider retinal venules associated with incident hypertension?. Hypertension 2006; 48(2): e10. author reply e11.

[13] Wong TY, Klein R, Sharrett AR, et al. Retinal arteriolar diameter and risk for hypertension. Ann Intern Med 2004; 140(4): $248-55$. [http://dx.doi.org/10.7326/0003-4819-140-4-200402170-00006] [PMID: 14970147]

[14] Cheung N, Sharrett AR, Klein R, et al. Aortic distensibility and retinal arteriolar narrowing: the multi-ethnic study of atherosclerosis. Hypertension 2007; 50(4): 617-22.

[http://dx.doi.org/10.1161/HYPERTENSIONAHA.107.091926] [PMID: 17698721]

[15] Wang JJ, Liew G, Wong TY, et al. Retinal vascular calibre and the risk of coronary heart disease-related death. Heart 2006; $92(11)$ : $1583-7$. [http://dx.doi.org/10.1136/hrt.2006.090522] [PMID: 16840510]

[16] Wong TY, Klein R, Sharrett AR, et al. Retinal arteriolar narrowing and risk of coronary heart disease in men and women. The atherosclerosis risk in communities study. JAMA 2002; 287(9): 1153-9. [http://dx.doi.org/10.1001/jama.287.9.1153] [PMID: 11879113]

[17] Klein R, Klein BE, Knudtson MD, Wong TY, Tsai MY. Are inflammatory factors related to retinal vessel caliber? The Beaver Dam Eye Study. Arch Ophthalmol 2006; 124(1): 87-94. [http://dx.doi.org/10.1001/archopht.124.1.87] [PMID: 16401789]

[18] Wang JJ, Taylor B, Wong TY, et al. Retinal vessel diameters and obesity: A population-based study in older persons. Obesity (Silver Spring) 2006; 14(2): 206-14.

[http://dx.doi.org/10.1038/oby.2006.27] [PMID: 16571845] 
[19] Ikram MK, de Jong FJ, Vingerling JR, et al. Are retinal arteriolar or venular diameters associated with markers for cardiovascular disorders? The Rotterdam Study. Invest Ophthalmol Vis Sci 2004; 45(7): 2129-34. [http://dx.doi.org/10.1167/iovs.03-1390] [PMID: 15223786]

[20] Wong TY, Islam FM, Klein R, et al. Retinal vascular caliber, cardiovascular risk factors, and inflammation: The multi-ethnic study of atherosclerosis (MESA). Invest Ophthalmol Vis Sci 2006; 47(6): 2341-50. [http://dx.doi.org/10.1167/iovs.05-1539] [PMID: 16723443]

[21] Wong TY, Duncan BB, Golden SH, et al. Associations between the metabolic syndrome and retinal microvascular signs: The Atherosclerosis Risk In Communities study. Invest Ophthalmol Vis Sci 2004; 45(9): 2949-54.

[http://dx.doi.org/10.1167/iovs.04-0069] [PMID: 15326106]

[22] Cheung N, Saw SM, Islam FM, et al. BMI and retinal vascular caliber in children. Obesity (Silver Spring) 2007; 15(1): 209-15. [http://dx.doi.org/10.1038/oby.2007.576] [PMID: 17228049]

[23] Sun C, Wang JJ, Mackey DA, Wong TY. Retinal vascular caliber: systemic, environmental, and genetic associations. Surv Ophthalmol 2009; 54(1): 74-95.

[http://dx.doi.org/10.1016/j.survophthal.2008.10.003] [PMID: 19171211]

[24] Gopinath B, Baur LA, Teber E, Liew G, Wong TY, Mitchell P. Effect of obesity on retinal vascular structure in pre-adolescent children. Int J Pediatr Obes 2011; 6(2-2): e353-9. [http://dx.doi.org/10.3109/17477166.2010.500390] [PMID: 20883126]

[25] Xiao W, Gong W, Chen Q, Ding X, Chang B, He M. Association between body composition and retinal vascular caliber in children and adolescents. Invest Ophthalmol Vis Sci 2015; 56(2): 705-10. [PMID: 25574054]

[26] de Onis M, Onyango AW, Borghi E, Siyam A, Nishida C, Siekmann J. Development of a WHO growth reference for school-aged children and adolescents. Bull World Health Organ 2007; 85(9): 660-7. [http://dx.doi.org/10.2471/BLT.07.043497] [PMID: 18026621]

[27] Li L-J, Ikram MK, Wong TY. Retinal vascular imaging in early life: insights into processes and risk of cardiovascular disease. J Physiol 2016; 594(8): 2175-203. [http://dx.doi.org/10.1113/JP270947] [PMID: 26435039]

[28] Egger M, Davey-Smith G, Altman D. Systematic reviews in health care: Meta-analysis in context. Philadelphia: John Wiley and Sons 2008.

[29] PRISMA. Preferred reporting items for systematic reviews and meta-analyses. Available from: http://www.prisma-statement.org/index.htm cited 2016 April 24.

[30] Stroup DF, Berlin JA, Morton SC, et al. Meta-analysis of observational studies in epidemiology: a proposal for reporting. Meta-analysis Of Observational Studies in Epidemiology (MOOSE) group. JAMA 2000; 283(15): 2008-12.

[PMID: 10789670]

[31] PROSPERO. International prospective register of systematic reviews. Available from: http://www.crd.york.ac.uk/PROSPERO/ [cited 2016 April 24]

[32] Wells GA, Shea B, O'connell D. The Newcastle-Ottawa Scale (NOS) for assessing the quality of nonrandomised studies in meta-analyses. Ottawa: The Ottawa Hospital 2000.

[33] Loney PL, Chambers LW, Bennett KJ, Roberts JG, Stratford PW. Critical appraisal of the health research literature: Prevalence or incidence of a health problem. Chronic Dis Can 1998; 19(4): 170-6. [PMID: 10029513]

[34] Yang DY, Guo K, Wang Y, et al. Intraocular pressure and associations in children. The Gobi Desert Children Eye Study. PLoS One 2014; 9(10): e109355. [http://dx.doi.org/10.1371/journal.pone.0109355] [PMID: 25295855]

[35] Akinci A, Cetinkaya E, Aycan Z, Oner O. Relationship between intraocular pressure and obesity in children. J Glaucoma 2007; 16(7): 627-30. [http://dx.doi.org/10.1097/IJG.0b013e318057528a] [PMID: 18091182]

[36] Hanssen H, Siegrist M, Neidig M, et al. Retinal vessel diameter, obesity and metabolic risk factors in school children (JuvenTUM 3). Atherosclerosis 2012; 221(1): 242-8. [http://dx.doi.org/10.1016/j.atherosclerosis.2011.12.029] [PMID: 22244041]

[37] Imhof K, Zahner L, Schmidt-Trucksäss A, Hanssen H. Association of body composition and blood pressure categories with retinal vessel diameters in primary school children. Hypertens Res 2016; 39(6): 423-9. [http://dx.doi.org/10.1038/hr.2015.159] [PMID: 26763853]

[38] Daniels SR, Lipman MJ, Burke MJ, Loggie JM. The prevalence of retinal vascular abnormalities in children and adolescents with essential hypertension. Am J Ophthalmol 1991; 111(2): 205-8. [http://dx.doi.org/10.1016/S0002-9394(14)72260-3] [PMID: 1992741]

[39] Gopinath B, Baur LA, Wang JJ, et al. Blood pressure is associated with retinal vessel signs in preadolescent children. J Hypertens 2010; 28(7): 1406-12.

[http://dx.doi.org/10.1097/HJH.0b013e3283395223] [PMID: 20410837] 
[40] Kurniawan ED, Cheung N, Cheung CY, Tay WT, Saw SM, Wong TY. Elevated blood pressure is associated with rarefaction of the retinal vasculature in children. Invest Ophthalmol Vis Sci 2012; 53(1): 470-4. [http://dx.doi.org/10.1167/iovs.11-8835] [PMID: 22205607]

[41] Murgan I, Beyer S, Kotliar KE, et al. Arterial and retinal vascular changes in hypertensive and prehypertensive adolescents. Am J Hypertens $2013 ; 26(3): 400-8$. [http://dx.doi.org/10.1093/ajh/hps091] [PMID: 23382491]

[42] Saw S-M, Chua W-H, Hong C-Y, et al. Height and its relationship to refraction and biometry parameters in Singapore Chinese children. Invest Ophthalmol Vis Sci 2002; 43(5): 1408-13.

[PMID: 11980854]

[43] Li L-J, Cheung CY, Chia A, et al. The relationship of body fatness indices and retinal vascular caliber in children. Int J Pediatr Obes 2011; 6(3-4): 267-74. [http://dx.doi.org/10.3109/17477166.2011.583657] [PMID: 21649537]

[44] Albuquerque LL, Gaete MI, Figueiroa JN, Alves JG. The correlation between body mass index and intraocular pressure in children. Arq Bras Oftalmol 2013; 76(1): 10-2.

[http://dx.doi.org/10.1590/S0004-27492013000100004] [PMID: 23812519]

[45] Gisthi O, Jade VW, Wong TY, Ikram MK, Gaillard R. Body fat distribution, metabolic and inflammatory markers and retinal microvasculature in school-age children. The Generation R study. Int J Obes 2015; 1-6.

[46] Jiang WJ, Wu JF, Hu YY, et al. Intraocular pressure and associated factors in children: The Shandong children eye study. Invest Ophthalmol Vis Sci 2014; 55(7): 4128-34.

[http://dx.doi.org/10.1167/iovs.14-14244] [PMID: 24876285]

[47] Kurniawan ED, Cheung CY, Tay WT, et al. The relationship between changes in body mass index and retinal vascular caliber in children. J Pediatr 2014; 165(6): 1166-1171.e1. [http://dx.doi.org/10.1016/j.jpeds.2014.08.033] [PMID: 25262303]

[48] Litwin M, Niemirska A, Sladowska-Kozlowska J, et al. Regression of target organ damage in children and adolescents with primary hypertension. Pediatr Nephrol 2010; 25(12): 2489-99. [http://dx.doi.org/10.1007/s00467-010-1626-7] [PMID: 20730452]

[49] Ding J, Wai KL, McGeechan K, et al. Retinal vascular caliber and the development of hypertension: A meta-analysis of individual participant data. J Hypertens 2014; 32(2): 207-15.

[http://dx.doi.org/10.1097/HJH.0b013e32836586f4] [PMID: 24322199]

[50] Gopinath B, Wang JJ, Kifley A, Tan AG, Wong TY, Mitchell P. Influence of blood pressure and body mass index on retinal vascular caliber in preschool-aged children 2013. [http://dx.doi.org/10.1038/jhh.2013.15]

\section{(C) 2017 Schuh et al.}

This is an open access article distributed under the terms of the Creative Commons Attribution 4.0 International Public License (CC-BY 4.0), a copy of which is available at: https://creativecommons.org/licenses/by/4.0/legalcode. This license permits unrestricted use, distribution, and reproduction in any medium, provided the original author and source are credited. 